\begin{tabular}{lllllllllllll}
$\mathbf{A}$ & $\mathbf{D}$ & $\mathbf{M}$ & $\mathbf{I}$ & $\mathbf{N}$ & $\mathbf{I}$ & $\mathbf{S}$ & $\mathbf{T}$ & $\mathbf{R}$ & $\mathbf{A}$ & $\mathbf{C}$ & $\mathbf{J}$ & $\mathbf{A}$ \\
\hline
\end{tabular}

ROCZNIKI NAUK PRAWNYCH

Tom XXIX, numer $2-2019$

DOI: http://dx.doi.org/10.18290/rnp.2019.29.2-9

\author{
ADRIAN SYPNICKI \\ NATALIA NACHULEWICZ
}

\title{
DOZÓR TECHNICZNY \\ W SYSTEMIE KONTROLI ADMINISTRACJI PUBLICZNEJ
}

\section{WPROWADZENIE}

Dozorem technicznym objęte są urządzenia techniczne, które zgodnie z art. 4 ust. 1 ustawy o dozorze technicznym ${ }^{1}$, mogą stwarzać zagrożenie dla życia, zdrowia, mienia oraz środowiska, m.in. przez rozprzestrzenianie się materiałów niebezpiecznych podczas ich magazynowania lub transportu. Dodatkowo, powyższe zagrożenie, może powstać także wskutek wyzwolenia energii (kinetycznej lub potencjalnej) przy przemieszczaniu ludzi lub ładunków w ograniczonym zasięgu, a także rozprężania się cieczy lub gazów znajdujących się pod ciśnieniem różnych od atmosferycznego.

Przez dozór techniczny, którego definicja zawarta jest w art. 2 ust. 1 u.d.t., rozumie się określone przez przepisy ustawy działania zmierzające do zapewnienia bezpiecznego funkcjonowania urządzeń technicznych oraz bezpieczeństwa publicznego w tych obszarach. Rodzaj urządzeń objętych dozorem został wymieniony wyżej. Należy dodać, że dozorem technicznym nie są objęte urządzenia, o jakich mowa $\mathrm{w}$ art. 3, tj. urządzenia techniczne, nad którymi są prowadzone prace naukowo-badawcze oraz górnicze szybowe urządzenia wyciągowe w tym także urządzenia techniczne w podziemnych wyrobiskach zakładów górniczych.

Dr ADRIAN SYPNICKI - doktor nauk prawnych; e-mail: adrian.sypnicki@gmail.com; https:/orcid. org/0000-0002-8995-7604

Mgr Natalia NachUlewicz - doktorant w Instytucie Nauk Prawnych, Wydział Prawa, Prawa Kanonicznego i Administracji Katolickiego Uniwersytetu Lubelskiego Jana Pawła II, Al. Racławickie 14, 20-950 Lublin; https://orcid.org/0000-0002-7303-0943

${ }^{1}$ Ustawa z dnia 21 grudnia 2000 r. o dozorze technicznym, Dz. U. z 2018 r., poz. 1351 z późn. zm. [dalej cyt.: u.d.t.]. 
Wobec konieczności zapewnienia bezpiecznego funkcjonowania urządzeń oraz bezpieczeństwa publicznego, co jest niezwykle istotne z punktu widzenia społeczeństwa, należy odpowiedzieć na pytanie, czym jest właściwie dozór techniczny oraz jaka jest jego pozycja w systemie kontroli administracji publicznej. Znaczenie omawianego zagadnienia przedstawia także art. 2 ust. 3 u.d.t. który wskazuje, że wykonywanie dozoru technicznego przez właściwe organy administracji nie zwalnia użytkowników urządzeń technicznych od odpowiedzialności za ich jakość oraz stan.

\section{DOZÓR TECHNICZNY}

Zgodnie z przytoczoną wyżej definicją dozór techniczny oznacza działania określone w u.d.t., zmierzające do zapewnienia bezpiecznego funkcjonowania urządzeń technicznych oraz zapewnienia bezpieczeństwa publicznego $\mathrm{w}$ tych obszarach. Kluczową kwestią jest wskazanie czy dozór techniczny można zakwalifikować jako kontrolę, nadzór, czy też jest to pojęcie odrębne zaliczane jedynie do systemu kontroli administracji ${ }^{2}$.

Próbując odpowiedzieć na powyższe pytanie należy rozpocząć od stwierdzenia, że dozór techniczny jest wykonywany przez jednostki dozoru technicznego, którymi stosownie do art. 4 pkt 3 u.d.t. jest Urząd Dozoru Technicznego [dalej: UDT] oraz specjalistyczne jednostki dozoru technicznego. Zakres zadań UDT zawarty w ustawie nie ułatwia odpowiedzi na postawione pytanie. Zgodnie z art. 37 pkt 1 u.d.t. do zadań urzędu należy nadzór i kontrola przestrzegania przepisów o dozorze technicznym, a także przepisów i zasad z zakresu bezpieczeństwa techniki, dotyczących urządzeń technicznych. Inaczej mówiąc, dozór techniczny jest wykonywany przez UDT i równocześnie do zadań tego organu należy m.in. nadzór i kontrola wykonywania przepisów o dozorze technicznym. Zastosowanie przez prawodawcę $\mathrm{w}$ jednym akcie normatywnym pojęć, które $\mathrm{w}$ nauce prawa

\footnotetext{
${ }^{2}$ Kontrola oraz nadzór zostały zdefiniowane w literaturze - zob. szerzej W. LaNG, Struktura kontroli prawnej organów państwowych PRL, Kraków: Uniwersytet Jagielloński, Państwowe Wydawnictwo Naukowe 1963, s. 39; S. JęDRZEJEwski, Kontrola administracji, Toruń: UMK 1976; J. JAGIELSKI, Kontrola administracji publicznej, Warszawa: LexisNexis 2012; M. SzEWCZYK, Nadzór $w$ materialnym prawie administracyjnym: administracja wobec wolności i innych praw podmiotowych jednostki, Poznań: Wydawnictwo Naukowe UAM 1995; S. JĘDrzeJEwsKi, H. Nowicki, Kontrola administracji publicznej. Kontrola a nadzór. Struktura systemu. Instytucje, Toruń: Comer 1995. W tym miejscu, należy jedynie wskazać, iż podstawową różnicę między kontrolą a nadzorem stanowi możliwość zastosowania wiążącej ingerencji w działalność danego podmiotu, w celu modyfikacji owej działalności do określonego kierunku, zgodnego z przyjętymi założeniami (JAGIELSKI, Kontrola administracji, s. 33).
} 
administracyjnego oznaczają różne powinności, wprowadza zamieszanie oraz utrudnia próbę wyraźnego wskazania czym jest dozór i jak należy go rozumieć.

Warto w tym miejscu przedstawić pogląd M. Szewczyka, który wskazuje na terminologiczną niekonsekwencję ze strony prawodawcy oraz piśmiennictwa, gdzie na określenie sytuacji właściwej dla nadzoru stosowane są inne pojęcia ${ }^{3}$. Jednym z takich pojęć jest, zdaniem tego Autora, właśnie dozór, który nie tylko występuje w prawie jako omawiany dozór techniczny, ale także jako dozór w zakresie wprowadzania do obrotu artykułów spożywczych ${ }^{4}$ czy też dozór w prawie atomowym (dozór jądrowy) ${ }^{5}$. M. Szewczyk stwierdza, że wcześniejsze akty normatywne dotyczące dozoru technicznego posługiwały się pojęciem nadzór, czego przykładem jest ustawa z 31 maja $1921 \mathrm{r}$. o nadzorze nad kotłami parowymi ${ }^{6}$. Posługiwanie się przez ustawodawcę w u.d.t. w sposób w istocie dowolny tymi terminami pozwala na stwierdzenie, iż dozór i nadzór są to pojęcia względem siebie synonimiczne. Przy takim założeniu M. Szewczyk formułuje postulat de lege ferenda, aby zastąpić termin nadzór przez dozór, bowiem dozorowi nie towarzyszy sugestia hierarchizowania jednego podmiotu względem drugiego ${ }^{7}$. $\mathrm{W}$ podobnym tonie wypowiada się J. Jagielski przyjmując, że dozór kojarzony jest „z cechą bezpośredniości oddziaływania, natomiast w przypadku nadzoru bardziej dostrzegać można cechę zwierzchnictwa"8. Ma to znaczenie zwłaszcza w tym kontekście, iż obecnie funkcjonujące inspekcje specjalne prowadzą swoją działalność względem podmiotów niewchodzących w skład aparatu administracji (niepaństwowe podmioty gospodarcze).

W literaturze technicznej (nieprawniczej) ujmowano dozór techniczny w transporcie kolejowym, którego zadaniem było „zapewnienie bezpiecznej i bezawaryjnej eksploatacji i napraw odpowiedzialnych zespołów taboru [...] zadania te sprowadzają się do nadzoru i kontroli stanu technicznego urządzeń dozorowanych oraz

\footnotetext{
${ }^{3}$ SzewCZYK, Nadzór w materialnym, s. 46.

${ }^{4}$ Rozporządzenie Prezydenta Rzeczypospolitej z dnia 22 marca 1928 r. o dozorze nad artykułami żywności i przedmiotami użytku, Dz. U. Nr 36, poz. 343 z późn. zm.

${ }^{5}$ Ustawa z dnia 29 listopada 2000 r. - Prawo atomowe, Dz. U. z 2014 r., poz. 1512 z późn. zm.

${ }^{6}$ Ustawa z dnia 31 maja 1921 r. o nadzorze nad kotłami parowymi, Dz. U. Nr 50, poz. 303. Zgodnie $\mathrm{z}$ art. 1 wszystkie kotły parowe podlegają nadzorowi władz rządowych. Art. 2 dodał, że przepisy o budowie i ustawianiu kotłów parowych oraz nadzorze nad nimi wydaje Minister Przemysłu i Handlu. Jednakże już art. 3 przewidywał, że wykonywanie dozoru nad kotłami parowymi władze rządowe mogą zlecić stowarzyszeniom właścicieli kotłów parowych. Dodatkowo art. 4 stanowił, że za dozór nad kotłami, wykonywany przez władze rządowe albo stowarzyszenia, należy uiścić stosowną opłatę. Podobne rozwiązanie, polegające na użyciu w tym samym akcie normatywnym pojęć nadzór oraz dozór, zostało ujęte w ustawie z 24 marca 1933 r. o nadzorze nad zbiornikami pod ciśnieniem, Dz. U. Nr 28, poz. 234.

${ }^{7}$ SzEWCZYK, Nadzór $w$ materialnym, s. 48.

${ }^{8}$ JAGIELSKI, Kontrola administracji, s. 40.
} 
kontroli przebiegu niektórych ważnych procesów technologicznych"9. Z tak ujętych zadań dozoru technicznego wynikają właśnie wymagania przewidziane w ramach dozoru technicznego dla konkretnego urządzenia technicznego, jak i konserwującego podmiotu, a także nadzorującej administracji technicznej ${ }^{10}$. Także w nowszej literaturze technicznej przyjmuje się, że „Zachowanie bezpieczeństwa publicznego to fundamentalna i wielowątkowa funkcja władzy państwowej. Włączenie do tych zadań dozoru technicznego jest konieczne, aby państwo mogło wywiązywać się ze swojego obowiązku [...] Konstytucja Rzeczpospolitej Polskiej wymienia kilka rodzajów bezpieczeństwa, $\mathrm{w}$ tym przede wszystkim bezpieczeństwo obywateli, państwa i środowiska (ekologiczne). Dozór techniczny ma w każdym z nich swój poważny udział, który rozwijał się przez ponad 105 lat. Zmieniał się jego zakres i zadania oraz rosło jego znaczenie w życiu publicznym" $"$.

$\mathrm{Z}$ przedstawionej literatury technicznej wynikają dwie ważne kwestie. Po pierwsze dozór techniczny dotyczy konserwacji danego urządzenia technicznego, przy czym dozorem objęte jest zarówno owo urządzenia jak i podmiot dokonujący konserwacji. Z kolei organy administracji publicznej sprawują jedynie nadzór nad przeprowadzeniem dozoru technicznego względem danego urządzenia. Po drugie nie występuje rozróżnienie między pojęciami nadzoru a dozorem technicznym, pojęcia te stosowane są synonimicznie ${ }^{12}$. Takie ujęcie dozoru technicznego pozwala na przyjęcie, iż termin ten stanowi w istocie nadzór, przy czym stosowanie pojęcia dozór wynika z pewnych tradycji danego środowiska i ogranicza je jedynie do kwestii technicznych.

W celu określenia czym jest dozór zasadne jest także sięgnięcie do mowy potocznej. Według Nowego słownika języka polskiego przez dozór rozumie się „opiekę wyznaczoną nad kimś lub nad czymś, mającą na celu dopilnowanie wykonania czegoś lub zapobieżenia czemuś, pilnowanie, doglądanie"13. Wydaje się, iż kluczowe znaczenie ma słowo „opieka” występujące w tej definicji, bowiem jest ono

${ }^{9}$ S. Bielecki, E. LeŚniak, Dozór techniczny w kolejnictwie. Spawanie gazowe, Warszawa: Wydawnictwo Komunikacji i Łączności 1984, s. 7.

${ }^{10}$ E. LeŚniak, S. Mazurkiewicz, S. Pawlak, Dozór techniczny w transporcie kolejowym, Warszawa: Wydawnictwo Komunikacji i Łączności, 1979, s. 24.

${ }^{11}$ A. ZıóŁkowski, Dozór techniczny a bezpieczeństwo publiczne, Biuletyn UDT „Inspektor Technika I Bezpieczeństwo”, 2017, nr 4, s. 4-5.

12 „Oficjalnie za początek dozoru technicznego i jego działalności uważa się datę wydania rozporządzenia Ministra Kolei Żelaznych z dnia 27.04.1922 r. o budowie i ustawianiu kotłów parowozowych i kotłów parowych ustawionych w wagonach kolejowych jako też o nadzorze nad nimi”, LeŚniaK, Mazurkiewicz, PaWlak, Dozór techniczny, s. 10.

${ }^{13}$ Nowy stownik języka polskiego PWN, red. E. Sobol, Warszawa: Wydawnictwo Naukowe PWN 2002. W taki sam sposób prezentowany jest dozór w Uniwersalnym słowniku języka polskiego PWN, red. S. Dubisz, Warszawa: Wydawnictwo Naukowe PWN 2006. 
tożsame z ujęciem dozoru prezentowanym w literaturze technicznej, gdzie dozór oznaczał zapewnienie konserwacji danego urządzenia. W takim znaczeniu dozór oznaczać będzie właśnie opiekę. Takie ujęcie dozoru ma istotne znaczenie, gdyż w nauce prawa administracyjnego w ramach celu nadzoru wyróżnia się ,istnienie opieki i wspierania podmiotów poddanych nadzorowi, czyli tzw. pieczę"14. Tym samym piecza stanowi element składowy nadzoru, ale także pełni samodzielną funkcję w odniesieniu do zadań samorządu zawodowego (m.in. lekarskiego) ${ }^{15}$. Warto zaznaczyć, iż terminem „piecza” posługuje się Konstytucja RP przyjmując w art. 17 ust. 1, iż w drodze ustawy można tworzyć samorządy zawodowe, reprezentujące osoby wykonujące zawody zaufania publicznego i sprawujące pieczę nad należytym wykonywaniem tych zawodów w granicach interesu publicznego i dla jego ochrony ${ }^{16}$. Na kanwie tego przepisu w piśmiennictwie przyjmuje się, że z charakteru prawnego pieczy wynika także jej funkcja o właściwościach władztwa publicznego ${ }^{17}$. J. Jagielski w ramach pieczy wyróżnia dwa znaczenia, tj. w znaczeniu ścisłym piecza to funkcja pomagania (wspierania) powiązana z nadzorem, która jest realizowana za pomocą środków o charakterze niewładczym; w znaczeniu szerokim piecza „wyraża sui generis funkcję opiekuńczą, obejmującą zarówno wspieranie i pomaganie, sprawowanie kontroli i nadzorowanie, jak również możliwość decydowania w określonym przez prawo zakresie o sytuacji podmiotu poddanego pieczy"18.

Ujęcie dozoru w ramach kategorii sprawowania opieki wskazywałoby, iż z punktu widzenia teoretycznego mamy do czynienia $\mathrm{w}$ istocie $\mathrm{z}$ pieczą, zaś różnica między tymi pojęciami dotyczy jedynie nazwy. W ocenie autorów nie byłby to pogląd prawidłowy, bowiem pojęcie dozór występuje już w pierwszych aktach dotyczących problematyki urządzeń technicznych. W $1911 \mathrm{r}$. władze rosyjskie zatwierdziły statut

${ }^{14}$ JAGIELSKI, Kontrola administracji, s. 34.

${ }^{15}$ Tamże.

${ }^{16} \mathrm{~W}$ ocenie H. Izdebskiego ,piecza obejmuje nie tylko to, co w ustawach korporacyjnych jest nazywane sprawowaniem nadzoru czy pieczy, ale również władcze decydowanie czy współdecydowanie o dopuszczeniu do wykonywania zawodu i ustalania zasad etyki, deontologii zawodowej". H. IZDEBSKI, Sprawowanie pieczy nad należytym wykonywaniem zawodu przez samorządy zawodowe, [w:] Zawody zaufania publicznego a interes publiczny - korporacyjna reglamentacja versus wolność wykonywania zawodu. Materiały z konferencji zorganizowanej przez Komisje Polityki Społecznej i Zdrowia Senatu RP przy wspóludziale Ministerstwa Pracy i Polityki Społecznej pod patronatem Marszałka Senatu RP Longina Pastusiaka 8 kwietnia 2002 r., Warszawa: Dział Wydawniczy Kancelarii Senatu: 2002, s. 35.

${ }^{17}$ P. SARneCKI, Radca prawny jako zawód zaufania publicznego, „Radca Prawny” 4-5 (2002), s. 27; M. KotUlski, Samorząd zawodowy, [w:] Instytucje współczesnego prawa administracyjnego. Księga jubileuszowa Profesora zw. dra hab. Józefa Filipka, red. I. Skrzydło-Niżnik, P. Dobosz, D. Dąbek [i in.], Kraków: Wydawnictwo Uniwersytetu Jagiellońskiego 2001, s. 377, 383.

${ }^{18}$ JAGIELSKI, Kontrola administracji, s. 35. 
Warszawskiego Stowarzyszenia dla Dozoru nad Kotłami Parowymi. Impulsem do podjęcia takiej inicjatywy była chęć minimalizacji wypadków powstających w ramach użytkowania kotłów parowych ${ }^{19}$. Po odzyskaniu przez Polskę niepodległości, w pierwszej ustawie dotyczącej urządzeń technicznych, tj. ustawie z dnia 31 maja 1921 r. o nadzorze nad kotłami parowymi, ustawodawca także używa pojęcia dozór. Nazwa tego aktu normatywnego zdaje się sugerować, iż dotyczył on nadzoru, lecz w art. 3 ust. 1 wyraźnie zaznaczono, iż to wykonywanie dozoru nad kotłami parowymi władze rządowe mogą zlecić stowarzyszeniom właścicieli kotłów parowych. Pozwala to na przyjęcie, iż posługiwanie się na przestrzeni ponad 90 lat $\mathrm{w}$ różnych aktach normatywnych terminem „dozór techniczny” nie jest tylko kaprysem ustawodawcy, lecz celowym działaniem, zaś termin jest odrębnym pojęciem względem nadzoru oraz kontroli. Istotne jest także, iż w art. 44 ust. 2 u.d.t. przyjmuje się, że wykonywanie dozoru technicznego nie obejmuje statków, których urządzenia objęte są nadzorem technicznym. Tym samym ustawodawca jednoznacznie przyjmuje rozróżnienie między dozorem technicznym a nadzorem, ograniczonym do kwestii technicznych (nadzór techniczny), mimo, iż nie definiuje tych pojęć.

W celu ustalenia czym jest dozór techniczny konieczne jest także dokonanie analizy regulacji zawartych w u.d.t. Stosownie do art. 13 ust. 1 pkt. 2 u.d.t. w ramach eksploatacji urządzeń technicznych objętych dozorem organy badają urządzenia poprzez badania techniczne (okresowe i doraźne), a także badania odbiorcze (w ramach gotowości do pracy). Ponadto organy sprawdzają zaświadczenia kwalifikacyjne osób obsługujących i konserwujących urządzenia techniczne. Oznacza to, że w ramach dozoru technicznego, odpowiednie organy dokonują badań technicznych urządzeń, co powoduje, że w tym miejscu mamy do czynienia z elementami właściwymi dla kontroli, bowiem badanie to nic innego jak ocena stanu faktycznego, porównanie go ze stanem postulowanym i postawienie diagnozy, w której zawarte są wnioski. Jednakże w art. 32 u.d.t. przyjęto, iż inspektor ma prawo odmówić wykonania czynności dozoru technicznego w przypadku wystąpienia niewłaściwych warunków do ich przeprowadzenia. Uprawnione wobec tego jest stwierdzenie, iż w ramach dozoru technicznego nie mamy do czynienia z klasycznym pojęciem kontroli, skoro inspektor uprawniony do jej przeprowadzenia może odmówić dokonania kontroli z uwagi na uchybienia, jakich dopuścił się podmiot kontrolowany.

Zgodnie $\mathrm{z}$ art. 9 u.d.t. właściwy organ wydaje $\mathrm{w}$ formie decyzji administracyjnej ,uprawnienie” umożliwiające wytwarzanie (naprawę lub modernizację) urządzeń technicznych przez zainteresowany podmiot. Decyzja ta jest wydawana po uprzednim stwierdzeniu m.in., że podmiot wdrożył właściwą technologię wytwarzania (naprawy lub modernizacji) oraz posiada urządzenia służące do wy-

\footnotetext{
19 ZıóŁkowski, Dozór techniczny, s. 5.
} 
twarzania (naprawy lub modernizacji) zgodnie $\mathrm{z}$ tą technologią. Wydanie takiej decyzji należy także uznać za część składową dozoru technicznego. Na dozór składają się działania zmierzające do zapewnienia bezpiecznego funkcjonowania urządzeń technicznych. Wydanie decyzji administracyjnej, w której określa się szereg warunków związanych z działaniem urządzenia, niewątpliwie wpisuje się w gwarancję bezpiecznego funkcjonowania urządzeń.

Warto także zaznaczyć, iż w u.d.t. zawarte zostały przepisy karne, które przewidują zastosowanie sankcji względem podmiotów dopuszczających się naruszenia przepisów u.d.t. $\mathrm{W}$ art. 63 ust. 1 pkt 1 podmiot dopuszczający się eksploatacji urządzenia technicznego bez otrzymania decyzji o dopuszczeniu urządzenia do eksploatacji lub obrotu podlega grzywnie albo karze ograniczenia wolności. Zgodnie ust. 2 tego przepisu tej samej karze podlega ten, kto przerabia urządzenie techniczne bez zgody organu właściwej jednostki dozoru technicznego. Możliwość zastosowania sankcji z uwagi na naruszenie przepisów u.d.t. zaliczyć można do elementów nadzorczych występujących w ramach dozoru technicznego.

Powyższe rozważania prowadzą do wniosku, iż dozór techniczny jest pojęciem odrębnym od kontroli, nadzoru czy też pieczy. Na dozór techniczny składają się elementy charakterystyczne dla tych pojęć, jednakże można w nim wskazać także elementy, które nie mogą zostać przypisane do żadnego z tych terminów, jak chociażby wydawanie uprawnienia wytwarzania, naprawy lub modernizacji urządzenia technicznego. Także możliwość odmowy dokonania przez inspektora czynności dozoru technicznego stanowi o swoistym novum właściwym wyłącznie dla dozoru technicznego. Dokonując zdefiniowania dozoru technicznego należy także uwzględnić jego cel, tj. zapewnienie bezpiecznego funkcjonowania urządzeń technicznych. W ocenie autorów przez dozór techniczny należy rozumieć wszystkie czynności, jakie są konieczne dla zapewnienia bezpiecznego funkcjonowania urządzeń technicznych, wśród których można wymienić czynności właściwe dla kontroli, nadzoru oraz pieczy. Podstawowym kryterium zdefiniowania dozoru technicznego powinien być jego cel oraz zakres przedmiotowy, ograniczony jedynie do urządzeń technicznych.

\section{DOZÓR TECHNICZNY JAKO RODZAJ POLICJI ADMINISTRACYJNEJ}

Przedstawione wyżej rozważania na temat rozumienia pojęcia dozór techniczny, odnieść należy do dokonanej w 2017 r zmiany u.d.t. Ustawodawca dokonał nowelizacji u.d.t. ${ }^{20}$ poprzez zmianę definicji dozoru technicznego zawartej w art. 2

${ }^{20}$ Art. 5 pkt 1 ustawy z dnia 9 listopada 2017 r. o zmianie niektórych ustaw w celu poprawy otoczenia prawnego działalności innowacyjnej, Dz. U. poz. 2201. 
ust. 1 u.d.t. dodając, że przez dozór techniczny, poza zapewnieniem bezpiecznego funkcjonowania urządzeń technicznych, należy rozumieć także działania zmierzające do zapewnienia bezpieczeństwa publicznego w obszarze funkcjonowania urządzeń technicznych i urządzeń do odzyskiwania par paliwa. Uwzględnienie w dotychczasowej definicji dozoru technicznego bezpieczeństwa publicznego należy uznać za zmianę pożądaną, a przy tym pozwalającą na pełną realizację przez władze państwowe funkcji bezpieczeństwa publicznego. Zauważyć należy, iż nowelizacja doprowadziła do usystematyzowania działalności organów administracji publicznej w zakresie dozoru technicznego, bowiem „ze względu na dzisiejszą, skomplikowaną sytuację na świecie i zagrożenia, jakie przynoszą nowe technologie, jednostki dozoru technicznego poszerzają kontekst swojego funkcjonowania, sprawiając, że ich działalność już dziś [sprzed nowelizacji - A.S. i N.N.] jest mocno osadzona w obszarze bezpieczeństwa publicznego"21.

$\mathrm{Z}$ punktu widzenia teoretycznoprawnego dokonana nowelizacja wymusza niejako odmienne spojrzenia na zagadnienie dozoru technicznego. Ujęcie w ramach tego pojęcia kwestii bezpieczeństwa publicznego implikuje konieczność rozważania czy dozór techniczny można rozpatrywać w kategorii policji administracyjnej.

W nauce prawa administracyjnego policja administracyjna traktowana jest jako jedna ze sfer ingerencji administracji, która obejmuje działania nakierowane na ochronę bezpieczeństwa, porządku i spokoju publicznego, a także życia, zdrowia oraz mienia ${ }^{22}$. Kwalifikacja danej instytucji jako policji może nastąpić na podstawie różnych kryteriów, przy czym za Z. Leońskim można przyjąć trzy kryteria, tj. materialne - instytucja bezpieczeństwa, formalne - nazwa użyta przez ustawodawcę w tekście aktu normatywnego, funkcjonalne - wykonywanie określonych zadań w sferze bezpieczeństwa ${ }^{23}$. W ocenie A. Matana o zakwalifikowaniu danego podmiotu jako policji decydują trzy cechy, tzn. środek, w jaki został wyposażony podmiot, oznaczający możliwość zastosowania przymusu, cel, którym jest nakierowanie na ochronę bezpieczeństwa oraz sposób realizacji celu obejmujący działania zmierzające do zapewnienia bezpieczeństwa ${ }^{24}$. Tym samym uprawnione wydaje się stwierdzenie, że policja administracyjna obejmuje organy administracji publicznej oraz organizacje społeczne wraz z podmiotami prywatnymi, które to podmioty

\footnotetext{
${ }^{21}$ ZıóŁкowski, Dozór techniczny, s. 4.

${ }^{22}$ Prawo administracyjne, red. J. Boć, Wrocław: Kolonia Limited 2010, s. 357.

${ }^{23}$ Z. LEOŃSKI, Istota i rodzaje policji administracyjnej (zagadnienia wybrane), [w:] Administracja publiczna u progu XXI wieku, Przemyśl: Wyższa Szkoła Prawa i Administracji w Przemyślu 2000,

${ }^{24}$ A. Matan, Policja administracyjna jako funkcja administracji publicznej, [w:] Nauka administracji wobec wyzwań wspótczesnego państwa prawa, red. J. Łukasiewicz, Rzeszów-Cisna: Tow. Nauk. Organizacji i Kierownictwa. Oddz. Rzeszów 2002, s. 352.
} s. 345-346. 
w ramach przyznanych im przez ustawodawcę kompetencji podejmują działania mające na celu ochronę bezpieczeństwa i porządku publicznego ${ }^{25}$. Podobnie pojęcie policji administracyjnej ujmowane jest w orzecznictwie sądów administracyjnych, gdzie przyjmuje się, że policja oznacza funkcję administracji związaną z ochroną takich wartości jak życie i zdrowie ludzi, porządek i bezpieczeństwo publiczne oraz konieczność zapobiegania poważnym szkodom mienia ${ }^{26}$.

Analizując pojęcie dozoru technicznego należy przyjąć, że mieści się ono w kategorii policji administracyjnej. Kwalifikacja dozoru technicznego następuje z punktu widzenia kryterium funkcjonalnego, tzn. ustawodawca określił, że dozór obejmuje czynności zmierzające do zapewnienia bezpiecznego funkcjonowania urządzeń oraz zapewnienia bezpieczeństwa publicznego w tym obszarze. Bezsprzecznie są to działania mieszczące się $\mathrm{w}$ ramach sfery bezpieczeństwa, o czym wspomina Z. Leoński. Co więcej, dozór techniczny spełnia także cechy kwalifikacyjne wskazane przez A. Matana. Jednostki dozoru technicznego zostały wyposażone w środek zastosowania przymusu (art. 18 u.d.t. przewidujący możliwość wstrzymania eksploatacji urządzenia technicznego w przypadku nieprzestrzegania przepisów o dozorze technicznym), celem dozoru jest zapewnienie bezpieczeństwa urządzeń technicznych oraz bezpieczeństwa publicznego w zakresie funkcjonowania tych urządzeń, a także realizacja celu obejmuje działania, które nakierowane są na zapewnienie bezpieczeństwa (art. 37 pkt 1 u.d.t. wskazujący, że do zadań UDT należy nadzór i kontrola przestrzegania przepisów o dozorze technicznym, a także przepisów i zasad z zakresu bezpieczeństwa techniki).

Uprawnia to tym samym do przyjęcia, że dozór techniczny mieści się w ramach pojęcia policji administracyjnej. Dozorowi technicznemu należy jednakże przypisać szczególny charakter w ramach policji administracyjnej. Przejawia się on w przyznaniu przez ustawodawcę jednostkom dozoru technicznego szerokiego zakresu zadań, które zmierzają do zapewnienia bezpieczeństwa. Ustawodawca bowiem w art. 37 pkt 1 u.d.t. stwierdził, że zadania UDT obejmują nadzór oraz kontrolę przestrzegania przepisów o dozorze technicznym. Do dozoru technicznego zalicza się wszystkie czynności, jakie są konieczne dla zapewnienia bezpiecznego funkcjonowania urządzeń technicznych, wśród których można wymienić czynności właściwe dla kontroli, nadzoru, a także pieczy. Uwypukla się w tym właśnie

\footnotetext{
${ }^{25}$ A. ChajBowicz, O podmiotowym znaczeniu pojęcia policja administracyjna, [w:] Nowe problemy badawcze w teorii prawa administracyjnego, red. J. Boć, A. Chajbowicz, Wrocław: Kolonia Limited 2009, s. 163.

${ }^{26}$ Por. wyroki: Wojewódzkiego Sądu Apelacyjnego w Warszawie z dnia 17 marca 2017 r., sygn. akt IV SA/Wa 2373/16; Wojewódzkiego Sądu Apelacyjnego w Gliwicach z dnia 19 maja 2016 r., sygn. akt II SA/G1 123/16; Wojewódzkiego Sądu Apelacyjnego w Kielcach z dnia 25 września 2014 r., sygn. akt II SA/Ke 608/14.
} 
szczególny charakter dozoru technicznego, bowiem pojęcia tego nie sposób jednoznacznie zakwalifikować do jednego ze wskazanych terminów prawa administracyjnego. Stanowi ono pewien synkretyzm pomiędzy kontrolą, nadzorem oraz pieczą, który połączony jest celem (zapewnieniem bezpieczeństwa) ograniczonym wyłącznie do urządzeń technicznych. Inaczej mówiąc, dozór techniczny zawiera w sobie elementy właściwe dla każdego z tych pojęć, przy czym z uwagi na cel oraz zakres przedmiotowy stanowi także jeden z rodzajów policji administracyjnej. Można przez to wyodrębnić dozór techniczny jako autonomiczne pojęcie od kontroli, nadzoru oraz pieczy. Dozór techniczny będzie cechował się szczególnym charakterem $w$ ramach policji administracyjnej oraz będzie obejmował wszystkie czynności niezbędne do zapewnienia bezpieczeństwa urządzeń technicznych oraz zapewnienia bezpieczeństwa publicznego w ramach tych urządzeń.

\section{JEDNOSTKI DOZORU TECHNICZNEGO}

W dalszej części rozważań stosowne wydaje się przybliżenie czym są i jak funkcjonują wspomniane już wcześniej jednostki dozoru technicznego. Potrzeba utworzenia jednostek dozoru technicznego pojawiła się wraz z rewolucją przemysłową i rosnącą liczbą poważnych wypadków spowodowanych użytkowaniem kotłów parowych. Pierwsze organizacje powstały już ponad sto lat temu, a ich celem była wówczas minimalizacja zagrożeń, jakie niosło ze sobą użytkowanie kotłów parowych. Przykładem jest Stowarzyszenie dla Dozoru nad Kotłami Parowymi, którego statut został zatwierdzony w 1911 r. przez władze rosyjskie.

Obecnie dozór techniczny jest wykonywany przez jednostki dozoru technicznego, którymi stosownie do art. 4 pkt 3 u.d.t. jest UDT oraz specjalistyczne jednostki dozoru technicznego.

Najistotniejszą instytucją jest właśnie UDT - państwowa osoba prawna, powołana w celu zapewnienia bezpieczeństwa urządzeń i instalacji technicznych podlegających dozorowi technicznemu. Organem UDT jest Prezes, powoływany przez ministra właściwego do spraw gospodarki. Kieruje on UDT przy pomocy wiceprezesa, dyrektorów i wicedyrektorów komórek organizacyjnych oraz Pełnomocnika Prezesa UDT do Spraw Ochrony Informacji Niejawnych. W ramach UDT działa również największa w Europie Centralnej jednostka notyfikowana UDT-CERT oraz jednostki certyfikujące systemy zarządzania, wyroby oraz osoby.

Podstawowy zakres działania UDT określa art. 37 u.d.t. i został już on pokrótce omówiony podczas próby wyjaśnienia czy dozór techniczny możemy utożsamiać z kontrolą bądź nadzorem. Warto jednak przypomnieć, iż do jego zadań należy nadzór i kontrola przestrzegania przepisów o dozorze technicznym, wykonywanie 
dozoru technicznego nad urządzeniami technicznymi, wydawanie odpowiednich decyzji administracyjnych, a także analizowanie przyczyn i skutków uszkodzeń urządzeń technicznych.

Swoje zadania UDT wykonuje przy pomocy właściwych oddziałów terenowych oraz Centralnego Laboratorium Dozoru Technicznego, które zostało powołane jako jednostka do spraw pomiarów technicznych i ekspertyz. Co więcej, UDT prowadzi samodzielną gospodarkę finansową. Jego przychodami są głównie przychody z opłat, a koszty działalności, w tym wynagrodzenia pracowników, pokrywane są z własnych środków.

W Polsce działają także specjalistyczne jednostki dozoru technicznego: Transportowy Dozór Techniczny podlegający Ministrowi Transportu oraz Wojskowy Dozór Techniczny podlegający Ministrowi Obrony Narodowej.

Transportowy Dozór Techniczny to państwowa osoba prawna, której zadaniem jest wykonywanie dozoru technicznego m.in. nad urządzeniami technicznymi zainstalowanymi na obszarze kolejowym, w kolejowych pojazdach szynowych oraz na bocznicach kolejowych, czy osobowymi i towarowymi kolejami linowymi oraz wyciągami narciarskimi. TDT kieruje Dyrektor powoływany i odwoływany przez ministra właściwego ds. transportu. Wyróżnić możemy także Wojskowy Dozór Techniczny, który wykonuje dozór techniczny nad urządzeniami technicznymi zainstalowanymi i eksploatowanymi w: jednostkach organizacyjnych Ministra Obrony Narodowej oraz przedsiębiorstwach, dla których Minister Obrony Narodowej jest organem założycielskim. Warto dodać że WDT w przeciwieństwie do wcześniej wymienionych jednostek, jest państwową jednostką organizacyjną i nie posiada osobowości prawnej. Organem WDT jest Szef WDT, powoływany i odwoływany przez Ministra Obrony Narodowej.

Przechodząc zaś do czynności dozoru technicznego należy wspomnieć, iż wykonują je pracownicy jednostek dozoru technicznego zwani inspektorami. Działają oni na podstawie upoważnienia wydanego przez organ właściwej jednostki dozoru technicznego oraz legitymacji służbowej. Mają możliwość dostępu do pomieszczeń, w których znajdują się urządzenia techniczne, przeprowadzania w wyznaczonych terminach badań, prób i pomiarów, czy wydawania zaleceń technicznych.

\section{PODSUMOWANIE}

Powyższy artykuł stanowi próbę odpowiedzenia na pytanie czym jest dozór techniczny oraz czy możemy go uznać za część składową systemu kontroli administracji publicznej. W świetle regulacji u.d.t. dozór techniczny jest pojęciem odrębnym od nadzoru oraz kontroli i nie może być z nimi utożsamiany, mimo, iż 
ustawodawca wskazał, że jednym z zadań UDT jest kontrola oraz nadzór nad przestrzeganiem przepisów u.d.t. Dozór techniczny obejmuje działania zmierzające do zapewnienia bezpiecznego funkcjonowania urządzeń technicznych, w tym badanie urządzeń technicznych, wydawanie w formie decyzji administracyjnej uprawnień w zakresie wytwarzania urządzeń technicznych, a także możliwość zastosowania sankcji względem podmiotów dopuszczających się naruszenia u.d.t. Tak ujęty dozór techniczny zawiera w sobie zarówno elementy właściwe dla kontroli, nadzoru, a nawet pieczy. Ujęcie dozoru technicznego wyłącznie jako swoistego synkretyzmu między nadzorem nie oddawałoby w pełni charakteru dozoru technicznego. Pojęcie to należy rozpatrywać także w kategorii policji administracyjnej o szczególnym charakterze. Przejawia się on w przyznaniu przez ustawodawcę jednostkom dozoru technicznego szerokiego zakresu zadań, które zmierzają do zapewnienia bezpieczeństwa. Szczególny charakter dozoru technicznego uwypukla się także w niemożności jednoznacznego zakwalifikowania go do jednego ze wskazanych terminów prawa administracyjnego. Dozór techniczny obejmuje bowiem wszystkie konieczne czynności do zapewnienia bezpiecznego funkcjonowania urządzeń technicznych, wśród których można wymienić czynności właściwe dla kontroli, nadzoru, a także pieczy. $Z$ tego względu dozór techniczny należy postrzegać jako autonomiczne pojęcie od kontroli, nadzoru oraz pieczy.

Dozór techniczny będzie cechował się szczególnym charakterem w ramach policji administracyjnej oraz będzie obejmował wszystkie czynności niezbędne do zapewnienia bezpieczeństwa urządzeń technicznych oraz zapewnienia bezpieczeństwa publicznego w ramach tych urządzeń. Podstawowym kryterium zdefiniowania dozoru technicznego jest jego cel oraz zakres przedmiotowy, ograniczony jedynie do urządzeń technicznych. Dodatkowo, dozór techniczny stanowi także element systemu kontroli administracji, gdyż można zaliczyć go do kategorii inspekcji specjalnych, tym samym podmiotów reprezentujących kontrolę wykonywaną przez administrację publiczną.

\section{BIBLIOGRAFIA}

\section{ŹRÓDŁA PRAWA}

Ustawa z dnia 31 maja 1921 r. o nadzorze nad kotłami parowymi, Dz. U. Nr 50, poz. 303.

Rozporządzenie Prezydenta Rzeczypospolitej z dnia 22 marca 1928 r. o dozorze nad artykułami żywności i przedmiotami użytku, Dz. U. Nr 36, poz. 343 z późn. zm.

Ustawa z 24 marca 1933 r. o nadzorze nad zbiornikami pod ciśnieniem, Dz. U. Nr 28, poz. 234. Ustawa z dnia 21 grudnia 2000 r. o dozorze technicznym, Dz. U. z 2018 r., poz. 1351 z późn. zm. Ustawa z dnia 29 listopada 2000 r. - Prawo atomowe, Dz. U. z 2018 r., poz. 792 z późn. zm. 
Ustawa z dnia 9 listopada 2017 r. o zmianie niektórych ustaw w celu poprawy otoczenia prawnego działalności innowacyjnej, Dz. U. poz. 2201.

\section{ORZECZNICTWO}

Wyrok Wojewódzkiego Sądu Apelacyjnego w Kielcach z dnia 25 września 2014 r., sygn. akt II SA/ Ke 608/14.

Wyrok Wojewódzkiego Sądu Apelacyjnego w Gliwicach z dnia 19 maja 2016 r., sygn. akt II SA/ G1 123/16.

Wyrok Wojewódzkiego Sądu Apelacyjnego w Warszawie z dnia 17 marca 2017 r., sygn. akt IV SA/ Wa 2373/16.

\section{LITERATURA}

BieleCKi Stefan, LeśNiak Erwin: Dozór techniczny w kolejnictwie. Spawanie gazowe, Warszawa: Wydawnictwo Komunikacji i Łączności 1984.

ChajBowicz Andrzej: O podmiotowym znaczeniu pojęcia policja administracyjna, [w:] Nowe problemy badawcze w teorii prawa administracyjnego, red. J. Boć, A. Chajbowicz, Wrocław: Kolonia Limited, 2009, s. od-do.

IZDEBSKI Hubert: Sprawowanie pieczy nad należytym wykonywaniem zawodu przez samorządy zawodowe, [w:] Zawody zaufania publicznego a interes publiczny - korporacyjna reglamentacja versus wolność wykonywania zawodu. Materiały z konferencji zorganizowanej przez Komisję Polityki Społecznej i Zdrowia Senatu RP przy współudziale Ministerstwa Pracy i Polityki Społecznej pod patronatem Marszałka Senatu RP Longina Pastusiaka 8 kwietnia 2002 r., Warszawa: Dział Wydawniczy Kancelarii Senatu 2002 r., s. 33-38.

JAGIELSKI Jacek: Kontrola administracji publicznej, Warszawa: LexisNexis, 2012.

JęDRZEJewski Stanisław, Nowicki Henryk: Kontrola administracji publicznej. Kontrola a nadzór. Struktura systemu. Instytucje, Toruń: Comer 1995.

JęDRZEJewSKi Stanisław: Kontrola administracji, Toruń: UMK 1976.

KotUlski Mariusz: Samorząd zawodowy, [w:] Instytucje współczesnego prawa administracyjnego.

Księga jubileuszowa Profesora zw. dra hab. Józefa Filipka, red. I. Skrzydło-Niżnik, P. Dobosz, D. Dąbek [i in.], Kraków: Wydawnictwo Uniwersytetu Jagiellońskiego 2001, s. 375-382.

LANG Wiesław: Struktura kontroli prawnej organów państwowych PRL, Kraków: Uniwersytet Jagielloński, Państwowe Wydawnictwo Naukowe 1963.

LEOŃSKI Zbigniew: Istota i rodzaje policji administracyjnej (zagadnienia wybrane). [w:] Administracja publiczna u progu XXI wieku, Przemyśl: Wyższa Szkoła Prawa i Administracji w Przemyślu 2000, s. 340-346.

LeŚniak Erwin, Mazurkiewicz Stanisław, Pawlak Stanisław: Dozór techniczny w transporcie kolejowym, Warszawa: Wydawnictwo Komunikacji i Łączności 1979.

Matan Andrzej: Policja administracyjna jako funkcja administracji publicznej, [w:] Nauka administracji wobec wyzwań współczesnego państwa prawa, red. J. Łukasiewicz, Rzeszów-Cisna: Tow. Nauk. Organizacji i Kierownictwa. Oddz. Rzeszów 2002, s. 350-354.

Nowy słownik języka polskiego PWN, red. E. Sobol, Warszawa: Wydawnictwo Naukowe PWN 2002. Prawo administracyjne, red. J. Boć, Wrocław: Kolonia Limited 2010.

SzEWCZYK Marek: Nadzór w materialnym prawie administracyjnym: administracja wobec wolności i innych praw podmiotowych jednostki, Poznań: Wydawnictwo Naukowe UAM 1995. 
Uniwersalny słownik języka polskiego PWN, red. S. Dubisz, Warszawa: Wydawnictwo Naukowe PWN 2006.

ZıóŁKowski Andrzej: Dozór techniczny a bezpieczeństwo publiczne, „Biuletyn UDT. Inspektor Technika i Bezpieczeństwo" 4 (2017), s. 4-5.

\section{DOZÓR TECHNICZNY \\ W SYSTEMIE KONTROLI ADMINISTRACJI PUBLICZNEJ}

Streszczenie

Artykuł przedstawia pojęcie dozoru technicznego oraz kwestię jego umiejscowienia w systemie kontroli administracji publicznej. Problematyka ta jest analizowana poprzez pryzmat celu, dla realizacji którego dozór techniczny został ujęty w aktach normatywnych oraz polityki administracyjnej, której przejawem jest dozór techniczny. Autorzy poddali analizie rozwiązania w zakresie dozoru technicznego prezentowane w literaturze nieprawniczej. Przedmiot rozważań stanowią także jednostki dozoru technicznego.

Slowa kluczowe: dozór techniczny; policja administracyjna; system kontroli administracji publicznej

\section{TECHNICAL SUPERVISION \\ IN THE PUBLIC ADMINISTRATION CONTROL SYSTEM}

\section{Su m mary}

The article presents the concept of technical supervision and the issue of its location in the public administration control system. This problem is analyzed through the prism of two concepts having a well-established meaning in science: control and supervision. The authors analyzed solutions in the field of technical supervision presented in non-legal literature. The subject of considerations are also technical supervision units.

Key words: technical supervision; control supervision; public administration control system 